\title{
PROJETO: COMPOSTA AUTOMÁTICA PARA USO RESIDENCIAL
}

\section{Maycon Manoel Sagaz, graduando em Design; Paulo Cesar Machado Ferroli, Dr. Eng. (UFSC)}

\section{INTRODUÇÃO}

No Brasil, a produção de material orgânico corresponde a mais de $50 \%$ do volume total de resíduos, segundo dados do Instituto de Pesquisa Econômica Aplicada (IPEA, 2016). De acordo com dados do IBGE (2012), 50,8\% desses resíduos são depositados em vazadouros a céu aberto (lixões); $27,7 \%$ em aterros sanitários e 22,5\% em aterros controlados. Analisando isso pode-se ver que esses resíduos, na sua maior parte, são depositados juntamente com os outros tipos de lixos sem nenhum tipo de tratamento específico, causando consequências negativas para o meio ambiente.

Uma dessas consequências é que o chorume produzido pela decomposição da matéria orgânica do lixo é um líquido altamente tóxico, que pode acabar contaminando o lençol freático que, por sua vez, contamina a origem da água que vem para as nossas residências. Sabe-se também que atualmente é real e urgente a mudança do pensamento e do hábito sobre as consequências das nossas ações com o meio em que vivemos. É necessário ter consciência de que tudo que consumimos gera lixo e esse lixo vai parar em algum local, que em sua maioria não é adequado. $O$ desafio é facilitar esse processo para as pessoas, para que organizem seu lixo e tratem seus resíduos orgânicos de maneira automatizada, reduzindo a problemática do lixo gerado.

Este resumo mostra o desenvolvimento de um produto que viabilize a compostagem residencial do lixo orgânico. $O$ projeto foi desenvolvido utilizando-se da metodologia projetual GODP - Guia de Orientação para o Desenvolvimento de Projetos desenvolvido por Merino (2016), que serve de apoio em todo processo de desenvolvimento.

\section{PROJETO}

Seguindo a metodologia proposta e complementando com técnicas projetuais encontradas em Pazmino (2013), aplicou-se no projeto análises diacrônica, sincrônica, funcional e estrutural. A figura 1 mostra a fase de geração de alternativas e a figura 2 mostra a aplicação da técnica do SCAMPER objetivando o final do processo criativo.
Figura 1 - Geração de alternativas.

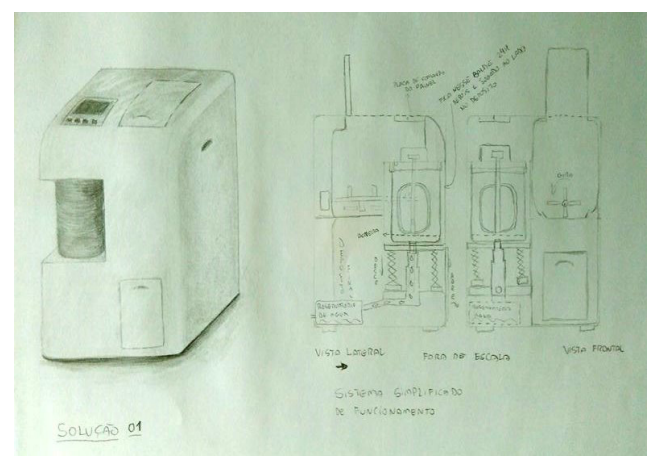

Figura 2 - Aplicação do SCAMPER

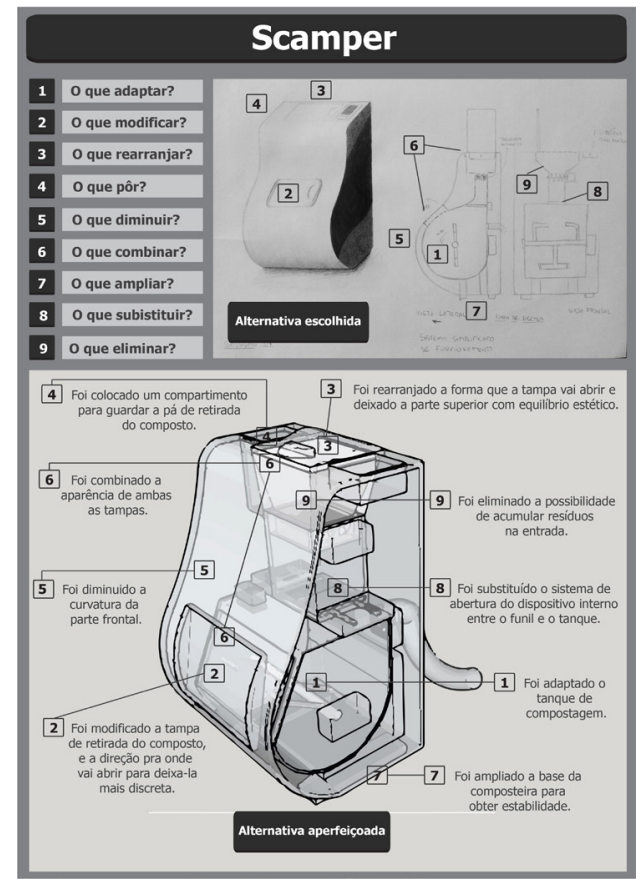

\section{CONCLUSÃO}

O projeto de um produto com abordagem sustentável é uma tendência atual. Os fatores ecológicos cada vez mais serão imprescindíveis para o sucesso de um produto, devendo naturalmente estarem interligados com os demais fatores de um projeto, como ergonômicos, fabris, estéticos, mercadológicos e financeiros, por exemplo. 
O projeto demonstrado neste artigo procurou balancear todos estes fatores, resultando em um produto adequado do ponto de vista da sustentabilidade, com análises de custo $\mathrm{x}$ benefício nos questidos ambiental, social e econômico, como se recomenda a abordagem ESA.

$\mathrm{O}$ uso de métodos de projeto no design mostrou a importância do procedimento sistematizado de projeto, com etapas bem definidas, utilizando-se para isso de um metodologia do tipo "aberta". A experimentação mostrou que esse tipo de metodologia é mais adequada para a inclusão da sustentabilidade no processo projetual do que o uso de métodos considerados "fechados".

\section{REFERÊNCIAS}

MERINO, Giselle Schmidt Alves Díaz. GODP - Guia de Orientação para Desenvolvimento de Projetos. NGD Núcleo de Gestão de Design/LDU - Laboratório de Design e Usabilidade. Florianópolis: UFSC, 2016.

PAZMINO, Ana Veronica. Como se cria, $\mathbf{4 0}$ métodos para design de produtos. São Paulo: Edgard Blucher, 2013.out. 2015. 